\title{
Role of Exclusive Breastfeeding in Preventing Diarrhea
}

\author{
Hanifah Rohmah ${ }^{1}$, Tisnasari Hafsah ${ }^{2}$, Lulu Eva Rakhmilla ${ }^{3}$ \\ ${ }^{1}$ Faculty of Medicine, Universitas Padjadjaran, ${ }^{2}$ Department of Child Health, Faculty of Medicine, \\ Universitas Padjadjaran/Dr. Hasan Sadikin General Hospital, Bandung, ${ }^{3}$ Department of \\ Epidemiology and Biostatistic, Faculty of Medicine, Universitas Padjadjaran
}

\begin{abstract}
Background: Breast milk has protective factors for infants' digestive tract. Infants are vulnerable to diseases, one of which is diarrhea. This cross-sectional study was designed to determine the relation between the proportion of diarrhea in infants and the administration of exclusive breastfeeding in Jatinangor.

Methods: This study was an observational study. Data on mothers with 6 months old infants were collected from Jatinangor Primary Health Center (PHC) infant records. The inclusion criteria applied were infants born in April 2012, alive, and living in Jatinangor subdistrict. One hundred and seventy one infants were recorded in April of 2012 in the PHC data. Thirty five were excluded because they were not born in April 2012. Another 45 were excluded because they were not permanent residents of Jatinangor subdistrict, while 4 infants died, and 23 had incomplete data. Therefore, only 66 infants were included as study subjects. Those infants came from 12 villages in the subdistrict of Jatinangor. Data collection was then performed using a questionnaire to the parents during the period of 21-31 October 2012.

Results: From 66 infants, the proportion of diarrhea was $66.7 \%$. Only $27.3 \%$ of all infants received exclusive breastfeeding. There was a difference in the proportion of diarrhea between infants who were exclusively breastfed and those who were not. Exclusive breastfeeding also reduced the risk of diarrhea $(0 R=0.26,95 \%$ CI 0.08-0.83).

Conclusions: There is a relation between the proportion of diarrhea in infants and exclusive breastfeeding in Jatinangor. Breastfeeding has a protective effect against diarrhea in infants.
\end{abstract}

Keywords: Diarrhea, exclusive breastfeeding, infants

\section{Introduction}

Immune system plays an important role against diseases, especially in infection. ${ }^{1}$ The Immune system of a newborn infant is still under developing progress that makes infants as the most susceptible group to be afflicted by infection, especially in the first years of life. Diarrhea is one of the most common diseases in infants, and toddlers as well. Diarrhea in the children can be fatal and often becomes a cause of death when improperly handled. In Africa and South East Asia, more than $80 \%$ of children's death are due to diarrhea. ${ }^{2}$

The incidence of diarrhea and its consequences on other part of gastrointestinal tract can be prevented by breastfeeding. According to Quigley et al. ${ }^{3}$, the incidence of diarrhea in infants who were breastfed was lower than those who were fed formula milk, this shows the role of breastmilk to control the disease.
In Indonesia, the proportion and mortality rate of diarrhea in the children are still high. According to Diarrhea Morbidity Survey which was done by the Ministry of Health in 2010, the greatest proportion of diarrhea patients in infants was the age group of 6-11 months which was $21.65 \%$. According to the report of Integrated Disease Surveillance 2009-2010, West Java is one of the province which most frequently agonized by an extraordinary event of diarrhea in the year of 2009 and $2010 .{ }^{4}$ In Sumedang regency, diarrhea makes the top ten of the most frequent diseases. ${ }^{5}$ The local government of Sumedang's data in the year of 2011 reported that diarrhea and upper respiratory tract infection are the two biggest killers in the district of Jatinangor. ${ }^{6}$

\section{Methods}

An observational study was performed on mothers with 6 months old infants. The

Correspondence: Hanifah Rohmah, Faculty of Medicine, Universitas Padjadjaran, Jalan Raya Bandung-Sumedang Km.21, Jatinangor, Sumedang, Indonesia, Phone: +6285311360123 Email: hanifah.rohmah@gmail.com 
data on these mothers were collected from Jatinangor Primary Healthcare Center (PHC) infant records. The inclusion criteria applied were infants born in April 2012, alive, and living in Jatinangor District. One hundred and seventy one infants were recorded in April of 2012 in the PHC data. Thirty five were excluded because they were not born in April 2012. Another 45 were excluded because they were not permanent residents of Jatinagor district, while 4 infants died, and 23 had incomplete data. Therefore,only a total of 66 infants were included as the study subjects. Those infants came from 12 villages in the district of Jatinangor. Data collection was then performed using a questionnaire to the parents during the period 21-310ctober 2012.

The variables included in the questionnaire study were the incidence of diarrhea and exclusive breastfeeding. Exclusive breastfeeding was defined as the consumption of breastmilk since the first day of life until the 6th month of age without any additional consumption. For infants who had baby formula, or had a mixture of breastmilk and formula diet were grouped as non-exclusive breastfeeding. Diarrhea was defined as experiences of defecation of 3 times or more in one day, or had liquid feces.
This study had received an ethical clearence from the Health Study Ethics Committe of Faculty of Medicine Universitas Padjadjaran, data were then analyzed using chi-square test.

\section{Results}

Out of 66 infants, the gender proportion was nearly balanced with 31 male infants and 35 femaleinfants. Diarrhea wasfound on 44 infants (66.67\%), while 22 had never had diarrhea. All 6 months old infants in the villages of Cisempur and Jatiroke have had diarrhea infants.

In this study 18 infants $(27.3 \%)$ had an exclusive breastfeeding, while 48 had a nonexclusive breastfeeding.The village with the highest proportion of exclusive breastfeeding was the village of Cileles which has 3 of 4 infants who were exclusively breastfed. Meanwhile, in Jatimukti, Cisempur, and Cibeusi there is no infant who was exclusively breastfed.

An association between the proportion of diarrhea in 6 months old infants and the exclusive breastfeeding was found. From a total of 48 infants who were not exclusively breastfed, 37 (77.1\%) had diarrhea and 11 infants $(22.9 \%)$ had never had diarrhea. Infants who were exclusively breastfed had

Table 1 General Characteristics of Infants in the District of Jatinangor

\begin{tabular}{lccc}
\hline & n (66) & Diarrhea(n=44) & $\begin{array}{c}\text { Exclusive } \\
\text { Breasfeeding (n=18) }\end{array}$ \\
\hline Gender & 31 & $18(27.3 \%)$ & $11(16.7 \%)$ \\
Male & 35 & $26(39.4 \%)$ & $7(10.7 \%)$ \\
Female & & & \\
Village & 8 & $3(4.6 \%)$ & $2(3.0 \%)$ \\
Cilayung & 8 & $7(10.6 \%)$ & $3(4.6 \%)$ \\
Mekargalih & 8 & $5(7.6 \%)$ & $3(4.6 \%)$ \\
Sayang & 7 & $7(10.6 \%)$ & $1(1.5 \%)$ \\
Jatiroke & 6 & $4(6.1 \%)$ & $2(3.0 \%)$ \\
Hegarmanah & 5 & $3(4.6 \%)$ & $2(3.0 \%)$ \\
Cintamulya & $1(1.5 \%)$ & $3(4.6 \%)$ \\
Cileles & 4 & $1(1.5 \%)$ & $2(3.0 \%)$ \\
Cikeruh & 4 & $3(4.6 \%)$ & $1(1.5 \%)$ \\
Cipacing & 4 & $2(3.0 \%)$ & 0 \\
Cibeusi & 4 & $3(4.6 \%)$ & 0 \\
Jatimukti & 4 & $4(6.1 \%)$ & 0 \\
Cisempur & 4 & & \\
\hline
\end{tabular}


less diarrhea experiences(44.4\%)

A significant difference was observed between infants who were and were not exclusively breastfed $(\mathrm{x} 2=5.50, \mathrm{p}=0.01)$. Exclusive breastfeeding also reduces the risk of diarrhea, exclusive breastfeeding has a protective effect against the diarrhea in infants. (OR= 0.26, 95\% CI 0.08-0.83).

\section{Discussion}

From the study, the proportion of diarrhea in the district of Jatinangor is still quite high (66.7\%) compared to the national data. According to the diarrhea morbidity survey conducted by the Ministry of Health in 2012, the proportion of diarrhea in infants of age less than 6 months is $11.86 \%$. The highest proportion of diarrhea in infants is the age group of 6-11 months at $21.65 \%$. Data from Riskesdas in 2007 shows that the highest proportion of diarrhea according to age group in toddlers of 1-4 years old which was $16.7 \%$ and West Java is the 9th most diarrhea afflicted province. ${ }^{4}$ The survey done by the local government of Sumedang shows that diarrhea is one of the top ten diseases in the district. ${ }^{5}$ Therefore, the local government of Sumedang District should give more attention to this health problem.

Exclusive breastfeeding's proportion in Jatinangor is still quite low, only $27.3 \%$ of infants were exclusively breastfed. Hoddinott et al. $^{7}$ states that breastfeeding can reduce the risk of infection and has a long term effect that can reduce the risk for obestity, hypertension, and reduce cholesterol level.

Another study by Ip et al. ${ }^{8}$ concludes that breastfeeding can reduce the risk of diarrhea on infants of less than one year of age compared to nonbreastfed infants (OR $0.36,95 \% \mathrm{CI} 0.18$ $0.74)$.

The event of diarrhea is lower in exclusively breastfed infants. According to Suradi ${ }^{9}$, this is because of the presence of sIgA (secretory Immunoglobulin A) in the breastmilk. SIgA has a role in the local protection on the mucous layer of the digestive tract. There are other protective contents in breastmilk such as IgG, IgM, IgD, Bifidobacterium bifidum, lactoferin, lactoperoxidase, lysozyme, macrophage, neutrophil, lymphocyte and lipids.

The role of breastfeeding in reducing infection of diseases can also be seen in the cohortstudy of Mihrshahi et al. ${ }^{10}$,stating that in infants who were exclusively breastfed for 6 months, the diarrhea proportion were $8.6 \%$ lower and the respiratory tract diseases are $20 \%$ lower $(\mathrm{p}=0.03)$ compared to non exclusively breastfed.

In another study, 150 infants were monitored and their enterovirus infection was monitored. Forty three percent of infants under the age of 1 year experiences an enterovirus infection. Breastfed infants of more than 2 weeks have lower rate of infection than those who were breastfed for less than two weeks (0.38 v 0.59 infections per infant). ${ }^{11}$

In this study it is found that there is a difference between the event of diarrhea in 6 months old infants who were exclusively breastfed and those who were not $(\mathrm{x} 2=5.50$, $\mathrm{p}=0.01$ ). Quigley et $a l^{12}$ performeda case control study with 167 cases and 137 controls, there is an association between nonbreastfed infants with the rise of diarrhea incidence.

Limitations of this study include the limited time and exclusion of factors such as social economy, parent's occupation, parental education, and immunization status in the analysis of this study.

As a conclusion, it is found that there is a relation between breastfeeding and the events of diarrhea in infants.

\section{References}

1. Baratawidjadja KG, Rengganis I. Imunologi dasar. Jakarta: Balai Penerbit FKUI; 2009.

2. UNICEF, WHO. Diarrhea: why children are still dying and what can be done. 2009 [Cited 2012 April 1]. Available from: http://www.who.int/maternal_child_ adolescent/documents/9789241598415/ en/index.html.

3. Quigley MA, Kelly YJ, Sacker A. Breastfeeding and hospitalization for diarrheal and respiratory infection in the united kingdom millennium cohort study. Pediatrics.2007;119(4):e837-42.

4. Kementerian Kesehatan Republik Indonesia. Situasi diare di Indonesia. Jakarta: Kementerian Kesehatan Republik Indonesia; 2011.

5. Departemen Kesehatan Kabupaten Sumedang. Sepuluh besar penyakit di kabupaten Sumedang. 2012 [Cited 2012 November 10]. Available from: http:// dinkes.sumedangkab.go.id/sepuluhbesar-penyakit-di-kabupaten-sumedang/.

6. Departemen Kesehatan Kabupaten Sumedang. Jumlah kematian bayi 2011. 2012 [Cited 2012 November 12]. Available from: http://dinkes.sumedangkab.go.id/ jumlah-kematian-bayi-2011/.

7. Hoddinott $P$, Tappin D, Wright C. Breastfeeding. BMJ.2008;336(7649):881 
8. Ip S, Chung M, Raman G, Chew P, Magula N, DeVine D, et al. Breastfeeding and maternal and infant health outcomes in developed countries. Evid Rep Technol Assess (Full Rep).2007;153:1-186.

9. Suradi R. Spesifitas biologis air susu ibu. Sari Pediatri.2001;3(3):125-9.

10. Mihrshahi S, Oddy WH, Peat JK, Kabir I. Association between infant feeding patterns and diarrheal and respiratory illness: a cohort study in Chittagong, Bangladesh. Int Breastfeed J. 2008;3:28.
11. Wall G. Outcome of breastfeeding versus formula feeding. La Leche League International.2010 [Cited 2012 November 14]. Available from: http://www.llli. org/docs/Outcomes_of_breastfeeding_ June_2007.pdf.

12. Quigley MA, Cumberland P, Cowden JM, Rodrigues LC. How protective is breastfeeding against diarrheal disease in infants in 1990s england? a case-control study. Arch Dis Child. 2006;91(3):245-50. 